\title{
ASSESSMENT OF PHYSICAL VIOLENCE AGAINST RESEARCH ASSISTANTS AND NURSES IN AN UNIVERSITY HOSPITAL
}

\author{
Oya Ogenler ${ }^{1}$, Gulcin Yapici
}

\begin{abstract}
The aim of this study was to determine the prevalence of physical violence and related factors among assistants and nurses. This cross-sectional study was included 166 research assistants and 209 nurses who worked at the University Hospital. The data was collected with a self-administered questionnaire. As $12.0 \%$ participants had a history of physical violence at workplace within the last 6 months. The perpetrator was a patient relative in 41 (78.8\%) and the patient himself/herself in 18 (34.6\%). The most common place of violence was emergency unit for the assistants and in-patient unit for the nurses. The emergency unit was observed to have a higher incidence of violence than other departments. One of every ten health care workers appears to be a victim of physical workplace violence. Between health care workers with patient/the relatives of the patient of the impact on relations the close of violence to be examined separately according to occupational groups. As a result, professional differences between nurses and doctors should be taken into consideration while investigating health violence. Each professions of healthcare have different professional practice and ethical obligations on the relationship between health care provider and patient/relatives.
\end{abstract}

Key words: workplace violence, physical abuse, hospital, occupational injuries, work

\section{Evaluación de la violencia física contra investigadores asociados y enfermeras en un hospital universitario}

Resumen: El objetivo de este estudio consiste en determinar la prevalencia de la violencia física y otros factores relacionados contra investigadores asociados y enfermeras. Este estudio transversal incluyó 166 investigadores asociados y 209 enfermeras trabajadores del hospital universitario. Los datos fueron recolectados mediante un cuestionario autoadministrado. $12 \%$ de los participantes informaron de violencia física en su lugar de trabajo en los últimos seis meses. El perpetrador fue un familiar de un paciente en 41 de los casos $(78,8 \%)$ y pacientes en 18 casos (34,6\%). La unidad de emergencia fue el lugar más común donde ocurrió la violencia para los investigadores asociados y la unidad de pacientes para las enfermeras. Se observó que la unidad de emergencia tuvo una mayor incidencia de violencia que otras unidades. Uno de cada 10 trabajadores de la salud es víctima de violencia física en el trabajo. Se examinó separadamente, según grupos de trabajo, el impacto en las relaciones de la violencia contra trabajadores de la salud por parte de pacientes o familiares de estos. Como resultado, se aconseja tener en consideración diferencias profesionales entre médicos y enfermeras cuando se investiga la violencia en el cuidado de la salud. Cada profesión del cuidado de la salud tiene diferentes prácticas profesionales y obligaciones éticas entre el proveedor de salud y el paciente y familiares.

Palabras clave: violencia en el lugar de trabajo, abuso físico, hospital, daños ocupacionales, trabajo

\section{Avaliação da violência física contra assistentes de pesquisa e enfermeiros em um hospital universitário}

Resumo: O objetivo deste estudo foi determinar a prevalência de violência física e fatores relacionados entre assistentes e enfermeiros/as. Este estudo transversal incluiu 166 assistentes de pesquisa e 209 enfermeiras que trabalhavam no Hospital Universitário. Os dados foram coletados através de um questionário autoaplicável. Como resultado, 12,0\% participantes apresentaram um histórico de violência física no local de trabalho nos últimos 6 meses. Como autores da violência foram identificados: os familiares dos pacientes em 41 questionários $(78,8 \%)$ e o paciente em si em 18 (34,6\%). O local mais comum de violência foi a unidade de emergência para os assistentes de pesquisa e a unidade de internação hospitalar para os enfermeiros/ as. Na unidade de emergência, observou-se que há uma maior incidência de violência do que em outros departamentos. Um de cada dez trabalhadores na área de saúde demonstra ser vítima de violência física no local de trabalho. O impacto das relaçōes de violência entre profissionais de saúde e pacientes/familiares deve ser examinado separadamente, de acordo com cada grupo ocupacional. Como resultado, diferenças profissionais entre médicos e enfermeiros/as devem ser consideradas ao investigar violência na área da saúde. Cada profissional de saúde possui diferentes práticas profissionais e obrigações éticas na relação entre médico e paciente / familiares.

Palavras-chave: violência no ambiente de trabalho, assédio físico, hospital, danos profissionais, trabalho

\footnotetext{
${ }^{1}$ Department of Ethics and History of Medicine, Faculty of Medicine, Mersin University, Mersin/Turkey Correspondence: oyaogenler@gmail.com

${ }^{2}$ Department of Public Health, Faculty of Medicine, Mersin University, Mersin/Turkey
} 


\section{Introduction}

The WHO defines violence as follows: "The intentional use of physical force or power, threatened or actual, against oneself, another person, or against a group or community, that either results in or has a high likelihood of resulting in injury, death, psychological harm, maldevelopment, or deprivation." Violence may be as physical, psychological and sexual violence or neglect. The act of physical violence may be in the form of beating, kicking, slapping, pulling, pushing, biting, or pinching $(1,2)$. Lately, there is a dramatic increase in all forms of violence worldwide(3). The WHO reports that more than 1.3 million people lose their lives each year. Violence-related mortalities comprise $2.5 \%$ of all deaths. Violence is the fourth most common cause of mortality between ages 15-44 years. Most of the deaths occur in low- and moderate-income countries. Since 2000, a total of 6 million people have died due to interpersonal violence $(1,4)$. Although there is no data involving mortality associated with direct physical violence, in 2014, Turkish Statistics Association noted that 16.018 people died from external injury and intoxication ( $4.3 \%$ of all deaths). The number of deaths in Mersin alone is 509(5). Moreover, thousands fall victim to nonmortal violence. Interpersonal nonmortal violence is more common than murder and may result in life-long social and health outcomes $(1,4)$.

Workplace violence is defined as "incidents where staff are abused, threatened or assaulted in circumstances related to their work"(6). Since violence affects all sectors and workers, health sector is also a risk group (2). $25 \%$ of all violent acts take place in the health sector. Health care workers suffer from violence 16 times more frequently than the other occupational groups. Health care workers are assaulted more frequently than guardians, police force, drivers, and bank employees. Half of health care workers are affected from violence. Among the health care workers, nurses suffer violence three times more often than others $(2,3)$. According to the study of European Foundation performed in 2000, 3 million of the 130 million workers in the European Union had suffered physical violence within the last 12 months(7). Studies abroad focusing on violence in the health sector report the frequency of physical violence suffered by health care workers as 3-58\% $(8,9,10)$. In Turkey, about $90 \%$ of health care workers suffer violence at work at least once in the previous 12 months, approximately quarter of them falling victim to physical violence(11). The frequency of physical violence among health care workers in Turkey was $1,8-52,5 \%(12,13)$. Violence towards health care workers is often perpetrated by patients and their relatives as well as visitors, peers and administrators $(8,14)$.

There are various factors increasing the risk of violence in health care institutions including 24hour service without interval, stressed-out family members, long waiting periods, and failure to reach healthcare services. Moreover, organizational factors involving inadequate physical environment, poor lighting, security flaws, poorly organized workflow, inadequate number of personnel, and lack of training to manage violence and overcrowd among personnel $(2,15,16)$.

According to Beauchamp and Childress, "first, do no harm" or "nonmaleficence" rule is obligation of nurse and doctors. Nonmalefience contains "do not kill", "do not cause pain or suffering", "do not incapacitate," "do not cause offense", "do not deprive others of the goods of life" (17). Unfortunately, clearly communicate that physical violence harms healthcare practioners. Healthcare worker who suffers from physical violence may find it difficult to comply with ethical principles.

Physical violence against health care workers has been increasing lately in Turkey. In this aim, this study was designed to determine the frequency of physical violence, environmental infrastructure of violence, and the post-violence procedures at the Mersin University Medical Faculty Hospital.

\section{Methods}

\section{Study design}

This cross-sectional study was performed on the research assistants and nurses working at the Mersin University Medical Faculty Hospital.

\section{Setting and sample}

Mersin University Medical Faculty Hospital is located in Mersin province, the Mediterranean Sea 
coast in Turkey. It is the general and governmental hospital. It is also a reference hospital for this region. The bed capacity of the hospital is 638 . Approximately 1000 patients are admitted outpatient clinics and 700 patients are admitted emergency departments per day. The period in which the study was conducted, 220 assistants and 317 nurses was working at the hospital. No sample size was determined in the study. It was aimed to reach all of them. There were no inclusion or exclusion criteria to work. Everyone who volunteered to participate in the work was included. However, a total of 375 workers, 166 assistants and 209 nurses, participated in the study. The participation rate was $75.5 \%$ for the assistants and $65.9 \%$ for the nurses, while the overall participation rate was $69.8 \%$.

\section{Ethical consideration}

The research protocol was approved by the Mersin University Social Sciences Ethics Committee, and permission to conduct the study was obtained from Mersin University Faculty of Medicine Administration.

\section{Instruments}

Data was collected with a self-administered questionnaire composed of 44 items which was prepared by the authors. The first section of the questionnaire included the sociodemographic characteristics, experiences in the profession, experiences at present workplace unit, working department, mean daily working time. Second section focused on anxiety about violence, history of physical violence during their profession lifetime and within the past 6 months. Third section comprised questions for the victims of physical violence demanding the characteristics of this violence as follows: type and time of physical violence, perpetrator's identity, status of the victim during violence, degree of injury, description of the location of violence, response of the victim during and after the incident, report status, preventability of the incident, outcome of the perpetrator, and lasting effects of the incident on victims.

\section{Data collection}

Assistants and nurses were given the survey forms at their workplaces after explaining the aim of the study. The participants filled out the forms by themselves. The study data were collected between November 1st - 31 December 2015. The results of the study were shared with the Hospital Administration and Deanery of Mersin University Faculty of Medicine.

\section{Data analysis}

Descriptive statistics (percentage, mean \pm standard deviation, median values) were employed to summarize the study data. The chi-square test was used to compare the categorical variables. The continuous variables were found to show no normal distribution, therefore, paired intergroup comparisons were carried out with Mann-Whitney $U$ and Spearman Correlation tests. $\mathrm{p}<0.05$ was considered to be statistically significant.

\section{Results}

Of the 375 study population, 166 (44.3\%) were assistants and 209 (55.7\%) were nurse. The mean age was $29.2 \pm 4.7$ years. As $66.9 \%$ of the participants were female, $55.5 \%$ were unmarried. The median experiences in the profession was 48.0 months (range 1-240 months) for the assistants and 69.0 months (range 1-349 months) for the nurses. The median experiences at present workplace unit was 20.5 months (range 1-60 months) for assistants and 12.0 months (range 1-180 months) for nurses. Moreover, the mean daily working time was $10.8 \pm 2.2$ hours for the assistants and $10.2 \pm 3.4$ for the nurses (Table 1).

Table 1. Participants demographic and professional characteristics

\begin{tabular}{|l|l|}
\hline Characteristics & \\
\hline Job category $(\mathrm{n}=375) \mathrm{n}(\%)$ & \\
Research assistants & $166(44.3)$ \\
Nurses & $209(55.7)$ \\
\hline Gender $(\mathrm{n}=375) \mathrm{n}(\%)$ & \\
Female & $251(66.9)$ \\
Male & $124(33.1)$ \\
\hline
\end{tabular}




\begin{tabular}{|c|c|}
\hline \multicolumn{2}{|l|}{ Marital status $(\mathrm{n}=375) \mathrm{n}(\%)$} \\
\hline Married & $167(44.5)$ \\
\hline Single & $208(55.5)$ \\
\hline \multicolumn{2}{|l|}{$\begin{array}{l}\text { Working department }(\mathrm{n}=187) \mathrm{n} \\
(\%)\end{array}$} \\
\hline Inpatient unit & $87(46.5)$ \\
\hline Intensive care unit & $45(24.1)$ \\
\hline Emergency unit & $31(16.6)$ \\
\hline Operating room/Reanimation & $13(7.0)$ \\
\hline Outpatient clinic & $11(5.9)$ \\
\hline Age (year) $($ Mean $\pm S D)$ & $29.2 \pm 4.7$ \\
\hline Number of children $($ Mean \pm SD) & $0.45 \pm 0.72$ \\
\hline $\begin{array}{l}\text { Daily working time (hour) } \\
(\text { Mean } \pm \text { SD) }\end{array}$ & $10.1 \pm 2.9$ \\
\hline Research assistants & $10.8 \pm 2.2$ \\
\hline Nurses & $10.2 \pm 3.4$ \\
\hline $\begin{array}{l}\text { Experiences in the profession } \\
\text { (month) (Median) }\end{array}$ & 49.0 \\
\hline Research assistants & 48.0 \\
\hline Nurses & 69.0 \\
\hline $\begin{array}{l}\text { Experiences at present workplace } \\
\text { unit (month) (Median) }\end{array}$ & 15.0 \\
\hline Research assistants & 20.5 \\
\hline Nurses & 12.0 \\
\hline
\end{tabular}

$87.2 \%$ of the participants had anxiety for workplace violence. When asked to rate their concerns from 0 to 9 , the level of anxiety was set at 5.0. No statistically significant difference was found between anxiety levels and gender, occupation, and unit studied ( $p>0.05)$. However, the level of anxiety of married people was higher than that of single $(\mathrm{p}<0.01)$. There was a weak positive correlation between anxiety level and experiences at present workplace unit and daily working time ( $\mathrm{p}$ $<0.05)$. Out of the $93(24.8 \%)$ participants stated that violence was a common occurrence in the workplace and $74(20.1 \%)$ were given training in violence in the hospital.
As $52(13.9 \%)$ participants had been victims of physical violence at least once in their professional lifetime $(14.5 \%$ in assistants and $13.4 \%$ in nurses), 45 (12.0\%) had suffered workplace physical violence at least once within the past 6 months $(13.3 \%$ in assistants and $11.0 \%$ in nurses). Median number of incidents was 2.0 (range 1-10 times) among violence victims. The most common form of the last physical violence was pushing (75.0\%) and kicking (17.3\%). Among 52 violence cases, the perpetrator was a patient relative in $41(78.8 \%)$ and the patient himself/herself in $18(34.6 \%)$. As $22(91.6 \%)$ research assistants had suffered violence from patient relatives and 5 (20.4\%) from patients, 19 (67.6\%) nurses had suffered violence from patient relatives and 13 (46.4\%) from patients. Only 3 of the victims were alone during the act of violence. The other 48 victims had someone at the site of violence such as patient, patient relative, security, and/or a supervisor (Table 2).

Table 2. Characteristics of physical violence

\begin{tabular}{|l|l|l|}
\hline Characteristics & $\mathrm{n}$ & $\%$ \\
\hline $\begin{array}{l}\text { Violence was a common } \\
\text { occurrence in the workplace } \\
\text { (n=375) } \\
\text { Yes }\end{array}$ & 93 & 24.8 \\
No & 241 & 64.3 \\
Do not know & 41 & 10.9 \\
\hline $\begin{array}{l}\text { Exposure to violence in their } \\
\text { professional lifetime (n=375) } \\
\text { Yes }\end{array}$ & 52 & 13.9 \\
No & 323 & 86.1 \\
\hline $\begin{array}{l}\text { Exposure to violence in the } \\
\text { past 6 months ( } \mathrm{n}=375)\end{array}$ & 45 & 12.0 \\
Yes & 330 & 88.0 \\
\hline No &
\end{tabular}




\begin{tabular}{|c|c|c|c|c|c|}
\hline $\begin{array}{l}\text { Type of physical violence } \\
(\mathrm{n}=52)^{\mathrm{a}}\end{array}$ & & & $\begin{array}{l}\text { Location of physical violence } \\
(\mathrm{n}=51)\end{array}$ & & \\
\hline Pushing & & & Inpatient unit & 23 & 45.1 \\
\hline Kicking & & & Emergency unit & 16 & 31.4 \\
\hline Pinch & & & Intensive care unit & 10 & 19.6 \\
\hline Other (throwing something, & & & Outpatient clinic & 2 & 3.9 \\
\hline (nting, waiking on it) & J & $1 \% .3$ & Secure place at the site of the & & \\
\hline $\begin{array}{l}\text { Perpetrators of physical } \\
\text { violence }(n=52)^{\text {a }}\end{array}$ & & & incident $(\mathrm{n}=50)$ & & \\
\hline Patient relative & 41 & 78.8 & Yes & & 14.0 \\
\hline & & & No & 39 & 78.0 \\
\hline Patients & 18 & 34.6 & Do not know & 4 & 8.0 \\
\hline $\begin{array}{l}\text { Colleagues } \\
\text { Supervisor }\end{array}$ & 2 & $\begin{array}{l}1.9 \\
3.8\end{array}$ & $\begin{array}{l}\text { Characteristics of the } \\
\text { environment with physical }\end{array}$ & & \\
\hline $\begin{array}{l}\text { People in the environment } \\
\text { during physical violence } \\
(\mathrm{n}=51)^{\mathrm{a}}\end{array}$ & & & $\begin{array}{l}\text { Bright } \\
\text { Loess }\end{array}$ & $\begin{array}{l}46 \\
4\end{array}$ & $\begin{array}{l}92.0 \\
8.0\end{array}$ \\
\hline $\begin{array}{l}\text { Patient relative } \\
\text { Patients }\end{array}$ & 28 & 54.9 & $\begin{array}{l}\text { Occurence of the violence } \\
\text { (hour) }(n=50)\end{array}$ & & \\
\hline Colleagues & 29 & 56.8 & $08.00-12.00$ & 6 & 12.0 \\
\hline $\begin{array}{l}\text { Colleague in superior } \\
\text { position }\end{array}$ & $\begin{array}{r}36 \\
7\end{array}$ & $\begin{array}{l}70.6 \\
13.7\end{array}$ & $\begin{array}{l}13.00-17.00 \\
18.00-24.00\end{array}$ & $\begin{array}{l}15 \\
24\end{array}$ & $\begin{array}{l}30.0 \\
48.0\end{array}$ \\
\hline Security & 12 & 23.5 & 01.00-07.00 & 5 & 10.0 \\
\hline Alone & 3 & 5.9 & Occurence of the violence & & \\
\hline $\begin{array}{l}\text { Work done during physical } \\
\text { violence }(\mathrm{n}=43)\end{array}$ & & & $\begin{array}{l}(\mathrm{n}=48) \\
\text { Working days }\end{array}$ & 37 & 77.1 \\
\hline $\begin{array}{l}\text { Diagnostic/therapeutic/ } \\
\text { caring procedures }\end{array}$ & 40 & 93.0 & Weekend & 11 & 22.9 \\
\hline Other works & 3 & 7.0 & The season of violence $(n=33)$ & & \\
\hline & & & Autumn & 4 & 12.1 \\
\hline & & & Winter & 5 & 15.2 \\
\hline & & & Spring & 8 & 24.2 \\
\hline & & & Summer & 16 & 48.5 \\
\hline
\end{tabular}




\begin{tabular}{|c|c|c|}
\hline $\begin{array}{l}\text { Need for treatment/care } \\
\text { following violent incident } \\
(\mathrm{n}=50) \\
\text { Yes } \\
\text { No }\end{array}$ & $\begin{array}{l}9 \\
41\end{array}$ & $\begin{array}{l}18.0 \\
82.0\end{array}$ \\
\hline $\begin{array}{l}\text { The first response of the } \\
\text { violence victims }(n=49)^{a}\end{array}$ & & \\
\hline Self-protect & & \\
\hline $\begin{array}{l}\text { Telling the perpetrator to } \\
\text { stop }\end{array}$ & $\begin{array}{l}28 \\
18\end{array}$ & $\begin{array}{l}57.1 \\
36.7\end{array}$ \\
\hline Escape & 12 & 24.5 \\
\hline Unresponsive & 8 & 16.3 \\
\hline Security call & 1 & 2.0 \\
\hline $\begin{array}{l}\text { What happened after the } \\
\text { violence }(\mathrm{n}=50)^{\text {a }}\end{array}$ & & \\
\hline $\begin{array}{l}\text { Reported the act of violence } \\
\text { to their unit chief }\end{array}$ & 22 & 44.0 \\
\hline Tell his/her colleague & 22 & 44.0 \\
\hline Tell a friend/family & 9 & 18.0 \\
\hline Did nothing & 9 & 18.0 \\
\hline Took the matter to the court & 3 & 6.0 \\
\hline $\begin{array}{l}\text { Was legal/administrative } \\
\text { action taken after the } \\
\text { incident? }(\mathrm{n}=50)\end{array}$ & & \\
\hline Yes & 11 & 22.0 \\
\hline No & 39 & 78.0 \\
\hline $\begin{array}{l}\text { What was done to the person } \\
\text { who committed the violence? } \\
(\mathrm{n}=50)\end{array}$ & & \\
\hline Nothing & 28 & 56.0 \\
\hline Oral warning & 15 & 30.0 \\
\hline Police notification/detention & 4 & 8.0 \\
\hline Prosecuted & 2 & 4.0 \\
\hline Location changed & 1 & 2.0 \\
\hline
\end{tabular}

\begin{tabular}{|l|l|l|}
\hline $\begin{array}{l}\text { The incident was of } \\
\text { preventable }(\mathrm{n}=50)\end{array}$ & 47 & 94.0 \\
Yes & 3 & 6.0 \\
No & & \\
\hline $\begin{array}{l}\text { Who can prevent the } \\
\text { incident? }(\mathrm{n}=47)^{\mathrm{a}}\end{array}$ & 33 & 70.2 \\
Security & 24 & 51.1 \\
Administration & 3 & 6.4 \\
Itself & 2 & 4.2 \\
Supervisor & \\
\hline
\end{tabular}

Note, ${ }^{a}$ More than one response option allowed

The most common location of physical violence was the inpatient unit (45.1\%), emergency unit (31.4\%), intensive care unit (19.6\%), and the outpatient clinic (3.9\%). Violence was more common in the emergency unit (52.2\%) for research assistants and in the inpatient unit for nurses $(57.1 \%)(\mathrm{p}=0.005)$. During the most recent act of violence, $83.3 \%$ of the assistants were working on diagnostic/therapeutic procedures of this patient, while $16.7 \%$ reported attending other patient's procedures. All of the nurses who experience violence, the act of violence was reported to take place during therapeutic or caring procedures. The act of violence often took place during 17.00-24.00 hours (48.0\%). The incident was more common during working days $(77.1 \%)$ and in summer (48.5\%). $78.0 \%$ of the violence victims reported having no secure place at the site of the incident (Table 2).

The first response of the violence victims during the incident was to self-protect in $28(57.1 \%)$ and telling the perpetrator to stop in 18 (36.7\%). In violence victims, $9(18.0 \%)$ had suffered from arm, hand, leg, or head injury, among whom 2 $(22.2 \%)$ had taken a medical report of their health status. Subsequent to the incident, $22(44.0 \%)$ of the victims reported the act of violence to their unit chief, $9(18.0 \%)$ did nothing, and $3(6.0 \%)$ took the matter to the court. While 39 (78.0\%) noted that no legal or administrative action had been taken after the incident, 15 (30.0\%) repor- 
ted that the perpetrator had been warned verbally. Forty-seven $(94.0 \%)$ of the victims thought that the incident was of preventable nature either by the security $(70.2 \%)$ or the administration (51.1\%) (Table 2).
History of suffering physical violence showed no significant relations with occupation, gender, marital status, age, number of children, experiences in the profession, experiences at present workplace unit, and daily working hours $(\mathrm{p}>0.05)$. However, there was a relation between physical

Table 3. Related factors associated with exposure to workplace physical violence-1

\begin{tabular}{|c|c|c|c|}
\hline Characteristics & $\begin{array}{c}\text { Physical violen } \\
\text { Yes } \\
\text { n ( \%) }\end{array}$ & $\begin{array}{l}\text { No } \\
\text { n (\%) }\end{array}$ & $P$ value \\
\hline \multicolumn{4}{|l|}{ Job category $(\mathrm{n}=375)$} \\
\hline Research assistants & $24(14.5)$ & $144(85.5)$ & .782 \\
\hline Nurses & $28(13.5)$ & $186(86.5)$ & \\
\hline \multicolumn{4}{|l|}{ Gender $(n=374)$} \\
\hline Female & $32(12.8)$ & $218(87.2)$ & .381 \\
\hline Male & $20(16.1)$ & $104(83.9)$ & \\
\hline \multicolumn{4}{|l|}{ Marital status $(\mathrm{n}=374)$} \\
\hline Married & $25(15.0)$ & $142(85.0)$ & .592 \\
\hline Single & $27(13.0)$ & $180(87.0)$ & \\
\hline \multicolumn{4}{|l|}{ Working department $(\mathrm{n}=187)$} \\
\hline Inpatient unit & $21(24.1)$ & $66(75.9)$ & .035 \\
\hline Intensive care unit & $12(28.9)$ & $32(71.1)$ & \\
\hline Emergency unit & $14(45.2)$ & $17(54.8)$ & \\
\hline Outpatient clinic & $3(27.3)$ & $8(72.7)$ & \\
\hline Operating room/Reanimation & $0(0.0)$ & $13(100.0)$ & \\
\hline
\end{tabular}


violence and work unit, emergency unit being the most common place of physical violence. Also, there was a significant association between workplace physical violence and anxiety levels. As median anxiety level was 7.0 in victims of physical violence, it was 5.0 in those with no history of violence $(\mathrm{p}<0.001)$ (Tables 3 and 4$)$.

Table 4. Related factors associated with exposure to workplace physical violence-2

\begin{tabular}{|l|l|l|l|}
\hline Characteristics & \multicolumn{2}{|l|}{$\begin{array}{l}\text { Physical violence } \\
(\mathrm{n}=367)\end{array}$} & P value \\
\hline & Yes & No & \\
\hline Median & Median & \\
\hline Age (year) & 28.0 & 29.0 & .397 \\
\hline Number of children & 0.0 & 0.0 & .142 \\
\hline $\begin{array}{l}\text { Experiences in the } \\
\text { profession (month) }\end{array}$ & 48.0 & 49.5 & .831 \\
\hline $\begin{array}{l}\text { Experiences at } \\
\text { present workplace } \\
\text { unit (month) }\end{array}$ & 16.0 & 15.0 & .895 \\
\hline $\begin{array}{l}\text { Daily working time } \\
\text { (hour) }\end{array}$ & 10.0 & 9.0 & .081 \\
\hline Anxiety level & 7.0 & 5.0 & $<.001$ \\
\hline
\end{tabular}

In the study, 87 (23.2\%) had witnessed physical violence to a healthcare worker in their workplace within the last 6 months. The witnessed physical violence was suffered by the nurses in $39(44.8 \%)$ and assistants in 37 (42.5\%). The perpetrator of the physical violence was a patient relative in 68 (78.1\%), patient in $13(9.1 \%)$, a superior healthcare worker in $8(9.1 \%)$, and a peer in $6(6.8 \%)$. The most common location of violence was the inpatient unit (48.2\%) and emergency unit (29.8\%).

\section{Discussion}

In this study, the anxiety levels among research assistants and nurses about workplace physical violence were higher and one out of ten participants was a victim of physical violence. Moreover, around a quarter of the participants had witnessed a peer subjected to physical violence. Studies that investigate the frequency of violence in healthcare workers in Turkey have different results. In the survey conducted by doctors working in medical faculties located in different regions in Turkey, Açik et al.(18) found that physical violen- ce is the most common in the Southeast region (33\%). In the Mediterranean or western region, they found similar results with our work (12\%) (18). In the study conducted by Ayranci et al. in the western region of Turkey, physical violence frequency $(11.7 \%)$ was determined similar to our study(13). Talas et al. found that the frequency of physical violence in emergency services in the capital of Turkey Ankara is quite high compared to our work. In this study, physical violence was determined as $37.3 \%$ in the emergency services of the university hospitals and $46.2 \%$ in the emergency services of state hospitals(19). Canbaz et al.'s study showed that, the frequency of physical violence in the emergency services in the province of Samsun located in the northern part of Turkey was determined as $18.4 \%(20)$. Both the studies conducted in Turkey $(13,18-20)$ and in other countries $(8,9,10,21)$, physical violence in healthcare workers is seen at different frequencies.

The difference may be associated with sociocultural differences between provinces or countries, working in different medical units (eg. emergency or psychiatry), daily patient load, institutional differences as well as characteristics of the health workers such as age and experiences in the profession. In some studies including ours, physical violence has a lower rate in university hospitals $(13,14,19)$. Although daily patient load was not asked in this and other mentioned studies, it is known that university hospitals receive less patients which may be contributing to the lower physical violence rates in addition to some of their positive attributes such as having quality personnel and higher service efficiency.

In this study, no significant difference was found between men and women regarding anxiety to suffer physical violence. However, studies show that women more commonly fall victim to physical violence than men, therefore feeling more anxious for possible physical violence $(10,11,20,22,23)$. Some authors note that women often fall victim to psychological and verbal violence, while men suffer more commonly from physical violence(11). $87.2 \%$ of the participants had anxiety for workplace violence, which was moderate levels. This finding has indications on the modes of health workers at workplace. Married ones showed higher levels of anxiety than those of the unmarried 
ones. This may be due to the fact that they felt more anxious because of the people they were responsible for. Moreover, higher daily working hours and experiences in the profession were associated with higher anxiety levels. Being in contact with patients for longer periods and having witnessed more events may be contributing to this. Also, similar to the literature, the ones who had suffered physical violence previously had higher levels of anxiety $(9-11,18,23)$.

Many studies in the literature report emergency units as the most common location for physical violence against health workers $(9,11,21,23)$. In our study, the most common location of violence was inpatient units followed by the emergency unit. However, the employees in the emergency service had more physical violence than the employees in other units. The patient characteristics, high patient load, physical conditions of the workplace, and inexperience of the workers may be contributing to the high frequencies of violence in the emergency unit $(9,23)$. However, we did not investigate the causes of violence in this study.

In our study, there was no difference between assistants and nurses with regard to frequency of physical violence. On the other hand some studies have shown higher rates among nurses in the literature(13). However, in this study, there were differences between the assistants and nurses in terms of location of violence, perpetrator of violence and activity during violence. As assistants generally suffered violence in the emergency department and from patient relatives, nurses often fell victim to violence in the inpatient unit where the perpetrator was the patient himself/herself in half of the cases. All the nurses suffered violence while caring/treating the patient, however, assistants received violence while dealing with other works, as well. The fact that nurses suffer violence while serving/treating the patient has further implications by disrupting the trust between patient and health worker. Negative consequences are observed when the nurse continues to serve the inpatient after falling victim to violence. Additionally, the safest working environment, which is the most natural right of the employee, stands out. In this study, similar to reports in the literature, the most common perpetrators of violence were patients and their relatives $(10,13,22,23)$.
The magnitude of the trauma induced in the health worker as a result of the physical violence may vary between loss of work for a couple of days and death $(6,14)$. In this study, one out of five of the victims were injured and among them, one out of five had received medical report. Unfortunately, less than half the participants had reported the incidence of physical violence to their administration, while $6 \%$ had taken the matter to court. Similarly, rates of unreported violence are higher in studies conducted in Iran, Taiwan, and Turkey $(10,18,19,22,23)$. Participants do not believe that there is benefit to reporting. Because no actions are being taken from the hospital management. Reporting violence bears utmost importance for the administration to see the risks at workplace in order to take effective precautinary steps and constitute a secure environment $(2,8)$.

The best way to reduce the risk of violence is noted to take the required security precautions. It is recommended to employ security personnel in risky sites, limit the entrance of patient relatives and/or visitors, put barriers in certain spaces and install alarm systems $(1,2)$. In present study, $78.0 \%$ of the violence victims reported absence of a secure place on site in face of physical violence. Moreover, a security personnel was present in $23.5 \%$ of the violence cases. As $9 / 10$ of the victims thought that the incident was preventable under proper conditions, $2 / 3$ of these victims believed could have been prevented by the security personnel and half of them thought it would have been prevented by the administration. The hospital administration should take certain physical and organizational precautionary steps to prevent violence in the hospital. There are some limitations to the present study. First, the data were collected retrospectively, which might lead to recall bias. Second, our work can't be generalized because it is done only in assistants and nurses working in an university hospital.

\section{Conclusion}

Physical violence is an important issue for assistants and nurses working in various units of the hospital. Effective legal or administrative measures must be applied to protect hospital personnel from violence. There were not significantly differences between occupation or gender and 
frequency of physical violence. However, there are differences between assistants and nurses with regard to location of violence, perpetrator, and activity during violence. As assistants often suffer violence from patient relatives in the emergency unit, nurses generally fall victim to violence in inpatient units from patients. In addition, all nurses suffer violence during a medical activity, while some assistants receive violence in the absence of medical activities. Therefore, the impact of relation between health worker and patient/ patient relative should be investigated in terms of different medical occupations. We believe that future interview studies should concentrate on the causes of physical violence against health workers and provide solutions to prevent such outcomes.

\section{Acknowledgement}

We would like to thank Elife KETTAS, Ayse ARSLANTAS and Mujde MORAN for their assistance in our data collection.

\section{Conflict of Interest}

The authors declare that there is no conflict of interest

\section{Funding}

This research received no specific grant from any funding agency in the public, commercial, or not-for-profit sectors.

\section{References}

1. Krug EG, Dahlberg LL, Mercy JA, Zwi AB, Lozanoet R. (eds). World report on violence and health. Geneva: World Health Organization; 2002.

2. International Labour Office/International Council of Nurses/World Health Organization/Public Services International. Framework Guidelines for Addressing Workplace Violence in the Health Sector. Geneva: International Labour Office; 2002.

3. Kingma M. Workplace violence in the health sector: a problem of epidemic proportion. Int Nurs Rev 2001; 48: 129-30. https://doi.org/10.1046/j.1466-7657.2001.00094.x

4. WHO. Global status report on violence prevention 2014. (updated 2015 Jun 21; cited 2016 Feb17); Availablefrom:http:// www.undp.org/content/dam/undp/library/corporate/Reports/UNDP-GVA-iolence-2014.pdf

5. Turkish Statistics Association (TÜİK). Regional statistics (updated 2015 oct 16; cited 2016 Feb17); Availablefrom:http// www.biruni.tüik.gov.tr/bolgeselistatistik/degiskenlerUzerindenSorgula.do

6. Warshaw L J. Workplace violence: preventive and interventive strategies. JOEM (Internet). 1996 October (updated 2015 may 1; cited 2016 Feb 12); 38: 993-1005. Available from: https://www.ncbi.nlm.nih.gov/pubmed/8899575

7. Chappell D, Di Martino V. Violence at work. (Internet) Third edition. Geneva: International Labour Office; 2006 (updated 2015 apr 2; cited 2016 Jan 19). Available from: http://www.ilo.org/global/publications/ilo-bookstore/orderonline/books/WCMS_PUBL_9221108406_EN/lang--en/index.htm

8. Di Martino V. Workplace Violence in the Health Sector: Country Case Studies-Brazil, Bulgaria, Portugal, Lebanon, South Africa, Thailand and Additional Australian Study. (Internet) 2002. (updated 2015 oct 16; cited 2016 April 27); Available from: http://www.who.int/violence_injury_prevention/injury/en/WVsynthesisreport.pdf,

9. Beech B, Leather P. Workplace in the health care sector: A review of staff training and integration of training evaluation models. Aggress Violent Behavior 2006; 11: 27-43. https://doi.org/10.1016/j.avb.2005.05.004

10. Fallahi-Khoshknab M, Oskouie F, Najafi F, Ghazanfari N, Tamizi Z, Afshani S. Physical violence against health care workers: A nationwide study from Iran. Iran J Nurs Midwifery Res. 2016; 21(3): 232-238. https://doi.org/10.4103/17359066.180387

11. Sağlik-Sen AR-GE Birimi. Sağlik Çalişanlari Şiddet Araştirmasi. Ankara: Sağlik-Sen Yayinlari-20, 2013.

12. Keser Özcan N, Bilgin H. Violence Towards Healthcare Workers in Turkey: A Systematic Review Turkiye Klinikleri J. Med. Sci 2011; 31 (6): 1442-1156. http://doi:10.5336/medsci.2010-20795

13. Ayranci U, Yenilmez C, Balci Y, Kaptanoglu C. Identification of violence in Turkish health care settings. J Interpers Violence 2006 Feb; 21(2): 276-96. https://doi.org/10.1177/0886260505282565

14. Ayranci U. Violence toward health care workers in emergency departments in west Turkey. J Emerg Med. 2005 Apr; 28(3): 361-365. https://doi.org/10.1016/j.jemermed.2004.11.018

15. Ogenler O, Yapici G. Patient- physician relationship in medical ethics education in the context of violence against healthcare workers: A short review. Int J Original Res (Internet) 2016 (updated 2015 oct 16; cited 2016 Sep 19); 2(8): 296300. Available from: http:/www.enrichscholarjournals.com/international-journal-of-original-research/2016/08/ 
16. Jane A. Lipscomb, Mazen El Ghaziri. Workplace Violence Prevention: Improving Front-Line Health-Care Worker And Patient Safety. New Solutions 2013; 23(2): 297-313. https://doi.org/10.2190/NS.23.2.f

17. Beauchamp TL, Childress JF. Principles of Biomedical Ethics (5th ed.). New York: Oxford University Press; $2001: 117$.

18. Açik Y, Deveci E, Gunes G, Gülbayrak C, Dabak S, Saka G, et al. Experience of workplace violence during medical speciality training in Turkey. Occupational Medicine 2008; 58: 361-366. https://doi.org/10.1093/occmed/kqn045.

19. Talas MS, Kocaöz S, Akgüç S. A Survey of Violence Against Staff Working in the Emergency Department in Ankara, Turkey. Asian Nursing Research 2011; 5: 197-120. http://doi.org/10.1016/j.anr.2011.11.001.

20. Canbaz S, Dündar C, Dabak Ş, Sünter AT, Pekşen Y, Çetinoğlu EÇ. Violence towards workers in hospital emergency services and in emergency medical care units in Samsun: an epidemiological study. Ulus Travma Acil Cerrabi Derg (Internet) 2008 (updated 2015 feb 16; cited 2015 May 21); 14(3): 239-244. 2002. Available from: https://www.ncbi.nlm. nih.gov/pubmed/18781422

21. Kowalenko T, Walters BL, Khare RK, Compton S. Workplace violence: a survey of emergency physicians in the state of Michigan. Ann Emerg Med. 2005 Aug; 46(2): 142-147. https://doi.org/10.1016/j.annemergmed.2004.10.010.

22. Chen WC, Sun YH, Lan TH, Chiu HJ. Incidence and risk factors of workplace violence on nursing staffs caring for chronic psychiatric patients in Taiwan. Int J Environ Res Public Health 2009; 6: 2812-2821. http://doi.org/10.3390/ ijerph6112812

23. Tang JS, Chen CL, Zhang ZR, Wang L. Incidence and related factors of violence in emergency departments-a study of nurses in southern Taiwan. J Formos Med Assoc. 2007; 106: 748-758. http://doi.org/10.1016/S0929-6646(08)60036-4

Received: November 28, 2017

Accepted: February 9, 2018 